mentioned in the standard accounts. Chapters 4 and 5 focus on the American years, and seek to place her career within a broader context of the difficulties faced by the independents as the American film industry consolidated and expanded its operations around a few big studios. Uncovering Guy Blaché thus makes visible a much more complex history of early cinema than previously suggested, and the books belongs to recent revisionist endeavours that suggest much more work on the hidden contribution made by women remains to be done.

'Of all the arts there is probably none in which (women) can make such splendid use of talents so much more natural to a woman than to a man and so necessary to its perfection,' observed Guy Blaché in her 1913 lecture at Columbia University. Maybe not a feminist in the modern sense, but in her statement that women were ideally suited for filmmaking Guy Blaché, McMahan argues, nonetheless demonstrated a feminist sensibility. Her films, and particularly her crossdressing comedies, are 'used to question, undermine, and subvert the socially delimited concept of gender' (p. 239). Her work placed enormous emphasis on female agency, in which women characters made choices, overcame obstacles set down by patriarchal society and shaped their own destinies. But perhaps the most important feminist trait of her work is the way she spoke to women, her direct feminine modes of address and her advocacy that women could achieve success on their own terms. Given her importance for the feminist canon and for early cinema, I find it quite astonishing that no sustained history has been undertaken until McMahan started this present study.

Alice Guy Blaché: Lost Visionary of the Cinema belongs to the Women Make Cinema series, a collection of titles committed to uncovering hidden histories and assessing the contribution made by women to the development of cinema. This book certainly fulfils the brief and is a welcome addition to this fascinating and laudable series. Taking 10 years to research, and involving extensive travels to locate sadly only a fraction of the thousand films directed by Guy Blaché, this book offers a comprehensive history of a truly remarkable woman and original filmmaker.

doi: 10.1057 /palgrave.fr. 9400345

Janet McCabe

\title{
Settler romances and the Australian girl
}

Tanya Dalziell; University of Western Australia Press, Crawley, 2004, 208p, ISBN 1-9206-9420-X £20.50 (Pbk)

Offering a detailed reading of turn-of-century adventure fictions and early ethnographies, this intriguing study explores how highly charged narratives of 
'whiteness' and 'femininity' serviced the invention of colonial Australia. Drawing upon the familiar symbolic figure of the cheeky, white, middle-class 'New Woman,' Dalziell defines the 'Australian Girl' as not merely a local representation of this controversial character, but rather as a regionally specific manifestation of race, gender, sexual, class, and colonial anxieties. By deconstructing fictional representations of this figure, the author seeks to understand how deeper ideological forces articulated with the emergence of a new Australian nationalism.

Selected texts animate a world of uncertain subjectivities. Dramatic encounters between the Australian Girl and imaginary 'natives' (whether fictitiously or ethnographically rendered) sustain the various narrative plots of these literary sources. Dalziell's analysis reveals how themes of alterity (or 'otherness') resulting from such adventures serve to highlight tensions over the fictitiousness of the (white) settler subject. Ultimately, they seek to reconcile the disorders of gender and class that so characterized life within this outpost of empire. Her close readings also expose the central ideological displacements through which new capitalist forms of economy (characterized by the extractive mining industry) become not only justified as inevitable, but naturalized as evolutionary progress within the appropriated landscapes of the colonial frontier.

Surprisingly, the role of Australian Federation (enacted in 1901) remains absent from this study. Could the ambiguous and contested subjectivities traced through these literary texts reflect a unique period of social instability while the disparate (and previously separate) Australian colonies searched for an imagined unity under national federation? As a collection of turn-of-century texts, do Dalziell's sources represent a specific, and possibly heightened, discourse of popular anxiety? Indeed, her discussion (p. 49) of the symbolic restoration of the settler economy and 'gendered racial identities,' through reference to British superiority, suggests the unspoken fear (and thus acknowledgement) of the artifice of this new antipodean nation. An explicit recognition of the Federation project might help situate the deployment of 'nationalism' as a profound, if displaced, theme throughout this literature. While the discursive conditions of nation-building are far from resolved in contemporary Australia, a point elegantly developed in the final chapter of the volume, the unique historic events that surrounded the original creation and consumption of this literature may well have influenced the particular nature of their 'ideological manoeuvers.'

To what degree can Australia be considered a 'post-colonial' nation? Dalziell's introduction offers a sophisticated interrogation of literature on 'settler' and 'second world' cultures. Of particular interest was her observation of heterogeneous conditions within both contemporary and colonial Australia: 'the ongoing processes of internal colonisation or so-called fourth world conditions that operate within, and often against, second world formations' (p. 17). Her study argues that anxieties of appropriation and displacement triggered by such stark and blatant inequalities achieve a form of resolution 
through the economic narratives of these adventure fictions. Gifts of mineral wealth 'freely' offered by imagined 'natives' to 'god-like' white explorers in the adventure romance An Australian Bush Track (1896) ultimately legitimate the establishment of extractive mining interests (pp. 64-65). In other words, as Dalziell observes, the traditional gift economy becomes inevitably replaced, or even 'improved,' by a settler capitalist economy. Simultaneously, since the gift transaction is performed by imaginary 'natives,' Aboriginal communities are effectively denied all ownership and connection to the imagined and adventurous lands.

Drawing from later revisions of Marcel Mauss's classic anthropological study The Gift (1950), Dalziell notes the polyvalent nature of the original gifts: the imaginary gold and diamonds 'move between the conditions of fetishised commodity, social use value and gifts' (p. 63). However, Dalziell's argument continues by negating the intrinsic materiality of the gifts. She defines the gift economy as essentially the social relations of debt and obligation that flow from object exchange. However, such an approach overlooks a basic premise of Mauss's original work. In a gift economy, both the social and material nature of 'the gift' sustain bonds of competition and solidarity between participants. In other words, the social relations are inalienable from the materiality of gifts, and vice versa. Indeed, in the ethnographic fieldwork that underlay his study, cycles of social reciprocity frequently involved a repetitive exchange of the same valued objects over time - these sacred gifts maintained and enhanced their ceremonial power through the sedimentation of exchange over multiple generations.

Perhaps the networks of power and knowledge that sustain the discursive and inherently unstable conditions of settler Australia operate similarly. Dalziell provides a detailed analysis of the power of language in the perpetuation of colonial formations, with various identity categories (including 'Australian') coming into existence through the seductive deployment of the words themselves. Would the materiality of this settler nation serve the same function (Cremin, 2001)? Australian historical archaeology has increasingly demonstrated how the 'heritage' (defined as both built environment and portable artefacts) of turnof-century Australia can be deconstructed to reveal equally potent and contested narratives of class, gender, race, and nationalism (Karskens, 1999; Lavelle, 2003; Casella and Fredericksen, 2004; Casella, 2005; Lydon and Ireland, 2005). To this audience, Dalziell's study offers a useful interdisciplinary and comparative example of the power of language in this colonial project. Ultimately, in foregrounding both the unstable nature of these fictitious subjectivities, and the socio-economic dynamics of these narratives, Dalziell offers compelling insight into the process of nation-building that continues to direct the politics of contemporary Australia.

Eleanor Conlin Casella 


\section{references}

Casella, E.C. (2005) 'Prisoner of his majesty: postcoloniality and the archaeology of British penal transportation' World Archaeology Vol. 37, No. 3: 453-466.

Casella, $\boldsymbol{\varepsilon}$.C. and Fredericksen, C. (2004) 'Legacy of the fatal shore: the heritage and archaeology of confinement in post-colonial Australia' Journal of Social Archaeology Vol. 4, No. 1: 99-125.

Cremin, A. (2001) 1901, Australian Life at Federation, Sydney: New South Wales University Press.

Karskens, G. (1999) Inside the Rocks: The Archaeology of a Neighbourhood, Sydney: Hale and Iremonger.

Lavelle, S. (2003) 'A tree and a legend: the making of past and place in the Blue Mountains, NSW' Journal of the Royal Australian Historical Society Vol. 89, No. 1: 1-25.

Lydon, J. and Ireland, T. (2005) Object Lessons: Archaeology and Heritage in Australia, Melbourne: Australian Scholarly Publishing.

Mauss, M. (1950) Cunnison, I., translator, The Gift, London: Cohen \& West.

doi: $10.1057 /$ palgrave.fr. 9400346

\section{High culture: reflections on addiction and modernity}

Anna Alexander and Mark S. Roberts (editors); State University of New York Press, Albany, 2002, 4l6p, ISBN 0-7914-5554-8£14.00 (Pbk); ISBN 0-7914$5553-\mathrm{X} £ 48.00$ (Hbk)

High Culture moves drug use and addiction from the margins of culture and the confines of the clinic to the very centre of literary, artistic and philosophical discourse. By exploring the role of addictive desire in the production of modernity, this collection of essays makes an original and scholarly contribution to the growing field of critical and cultural studies of addiction.

The editors state that the book was 'conceived in a mode of "high" philosophical and ethico-political experimentation' (p. xi) and certainly readers will not find simple models of addiction or solutions to drug problems within its pages. The volume is refreshingly free from the pathologizing and therapeutic impulse. Instead, it connects addiction to 'fundamental questions about subjectivity, ontology, and desire, as well as political/ideological issues of representation, identification, and control' (p. xi).

The collection contains 17 chapters, many based on papers presented at a conference on Addiction and Culture held in Claremont, California in 1996. Another volume of essays, High Anxieties: Cultural Studies in Addiction, edited by Janet Farrell Brodie and Marc Redfield, also originated in this landmark conference and was published in 2002 (the author has an essay in this volume).

The first section of High Culture 'Philosophical and Literary Reflections on Addiction' contains essays on Nietzsche and the Dionysian high; Benjamin's hashish writings (and his writing addiction); Schelling and Heidegger; Burroughs 